\title{
Literatura indigena: questões de identidades numa perspectiva engajada em Daniel Monduruku'
}

Leandro Faustino Polastrini²

Universidade Federal do Mato Grosso.

Mario Cezar Silva Leite ${ }^{3}$ Universidade Federal do Mato Grosso.

Artículo de reflexión derivado de investigación

Recibido: 17 de agosto de 2012 - Aprobado: 19 de octubre de 2012

\section{Resumo:}

Este ensaio é uma análise do livro Banquete dos Deuses - Conversa sobre a origem da cultura brasileira (2000), balizada no engajamento do escritor indígena Daniel Munduruku. As bases teóricas deste trabalho estão em Sartre (1989) e Denis (2002). O resultado desta investigação remete à discussão sobre a identidade cultural e étnica dos índios brasileiros; há a busca da dessacralização de uma má identidade construída dos indígenas, aquela do selvagem, do atrasado, do antropofágico e como seres do passado (folclorização), apresentando o confronto entre dessacralização e sacralização da formação de novas identidades indígenas na contemporaneidade.

Palavras-chave: literatura indígena, identidades, engajamento, Daniel Munduruku.

Este artigo é resultado do projeto "Transculturação e Identidades na Obra de Daniel Munduruku" financiado pela Fundação de Apoio à Pesquisa do Estado do Mato Grosso, 20 I 0-20 I I. Dissertação de Mestrado em em Estudos de Linguagem, UFMT, 200 I, orientada por Mário Cezar Silva Leite.

2 Mestre em Estudos de Linguagem (área de concentração Estudos Literários) - Universidade Federal do Mato Grosso. leandropolastrini@yahoo.com.br

3 Doutor em Comunicação e Semiótica; professor do Departamento de Letras da Universidade Federal de Mato Grosso Universidade Federal de Mato Grosso.

mcsl@terra.com.br 


\title{
Literatura indígena: problemática de las identidades en una perspectiva comprometida en Daniel Munduruku
}

\begin{abstract}
Resumen:
Este ensayo es un análisis del libro: Banquete dos Deuses: Conversa sobre a origem da cultura brasileira (2000), basado en el compromiso del escritor indígena Daniel Munduruku, utilizando como bases teóricas a Sartre (1989) y a Benoit (2002). El resultado de este estudio remite a una discusión acerca de la identidad cultural y étnica de los indios brasileños, contribuyendo con ello a la desacralización de una mala identidad construida de los indígenas, aquella que los ve como salvajes, atrasados, antropofágicos y como seres del pasado (folklorización), perspectiva que ha llevado a una confrontación entre la desacralización y sacralización de la formación de nuevas identidades indígenas en la contemporaneidad.
\end{abstract}

Palabras-clave: literatura indígena, identidades, compromiso, Daniel Munduruku.

\section{Indigenous literatura: issues about identities in a perspective committed in Daniel Munduruku}

\begin{abstract}
:
This study is an analysis of the book Feast of the Gods: Talk about the origin of Brazilian culture (2000), guided the engagement of indigenous writer Daniel Munduruku, the theoretical basis of this work are in Sartre (1989), Denis (2002). The result of this research to the discussion about the cultural and ethnic identity of Brazilian Indians, there is the pursuit of desecration of a constructed identity of the indigenous poor, that's wild, late, and as the cannibalistic beings of the past (folklorization), presenting the confrontation between desecration and consecration of the formation of new identities in contemporary indigenous.
\end{abstract}

Keywords: Indigenous literature, identity, engagement, Daniel Munduruku.

\section{Introdução}

Ninguém é escritor por haver decidido dizer certas coisas, mas por haver decidido dizê-las de determinado modo. ${ }^{3}$

Antonio Candido aponta em livro Literatura e Sociedade ${ }^{4}$ que foi a partir do romantismo que iniciaram os primeiros estudos da literatura brasileira em relação ao seu surgimento, e como na época o espírito

3 SARTRE, Jean-Paul. O que é a Literatura? São Paulo: Ática, 1989, pág. 22

4 CÂNDIDO, Antonio. Literatura e Sociedade: estudos de teoria e história literária. São Paulo: Nacional, 1975, 4a ed. rev., pág. 89. 
nacionalista estava impregnado na classe artística, a busca era por expressões da realidade local, aspectos tipicamente brasileiros, logo a natureza e o índio. Candido destaca como um dos representantes mais radicais desse período, Joaquim Norberto, o qual chegou a imaginar uma literatura indígena, autenticamente brasileira, que não estava sujeita à malícia do colonizador e poderia desempenhar o papel de formadora, assim como foi atribuído à portuguesa.

Porém, não é desta literatura que propomos tratar neste estudo, a indianista dos escritores românticos como José de Alencar e Gonçalves Dias. Na contemporaneidade podemos identificar a existência de uma produção literária de autoria indígena, que utiliza a escrita do não índio, para desmistificar e apresentar uma visão diferenciada das literaturas românticas, naturalistas/realistas, difundindo outra, mais próxima do indígena brasileiro nos dias de hoje, uma composição identitária híbrida. Portanto, atribuir a essa literatura o caráter de engajada.

Candido ${ }^{5}$ destaca a importância da escrita na literatura, em que um escritor da época, tratando da linguagem literária, exprime bem esse fato ao dizer que a invenção da escrita "tornou possível a um ser humano criar num dado tempo e lugar uma série de sinais a que pode reagir com outro ser humano noutro tempo e lugar". Trataremos aqui sobre a importância da escrita, e como os indígenas letrados, alfabetizados, ou melhor, formados na língua portuguesa a estão utilizando. Sabemos que existiam e existem povos indígenas que não possuem um sistema de escrita de suas línguas, logo os meios de transmissão de conhecimento e informações ocorrem pela tradição oral, ou seja, os costumes, lendas e mitos, são passados de gerações em gerações com o uso da fala. $\bigcirc$ que contém uma grande riqueza cultural não registrada em livros ou códigos (salvo as pinturas corporais, símbolos), apesar de nas últimas décadas muitos antropólogos e estudiosos da linguística se dedicarem a codificar e catalogar as línguas indígenas que não possuem esse sistema gráfico.

Nesta perspectiva, dizemos que os povos indígenas no Brasil estão se organizando tal como a sociedade ocidental, utilizando o processo de escrita e de organização social; porém, sem deixarem seus costumes e crenças desaparecerem, como uma forma de resistência. Por isso, o índio começa a escrever e contar sua própria história, com sua singularidade étnica; ganha voz e espaço na sociedade junto às demais minorias excluídas, abalando a hegemonia do adulto, branco, civilizador, que no processo de colonização e estruturalização de uma nação, afirmava sua cultura em detrimento das demais.

Nossa gente, no entanto, não se entregou, não capitulou. Ao contrário, mostrou que era capaz de lutar pelo que acreditava, lutar por seus princípios, por seus valores, por sua vida e pela vida de seus filhos. Dessa forma, passou a entender o pensamento quadrado dos conquistadores, a lógica que está por trás de tanto egoísmo. Fez isso indo à escola, convivendo nos espaços urbanos, servindo nos quartéis militares, estudando na universidade. Foi criando uma resistência maior e

$5 \quad$ Ibidem, pág. 25. 
articulando entre si para dar uma resposta a tamanha discriminação. Assim surgiu o movimento indígena organizado. ${ }^{6}$

De acordo com Joana Fernandes, ${ }^{7}$ a cultura é um conjunto de traços como: religião, economia, organização familiar, arquitetura, vestimentas, e quando culturas humanas (diferentes) entram em contato uma com a outra, transformam-se com o passar do tempo por influência mútua. Fernandes destaca que se o contato for muito intenso, a mais forte acaba exercendo maior poder sobre a mais fraca, acontecendo à absorção ou assimilação de uma pela outra, fazendo com a mais fraca desapareça enquanto sociedade.

Desta forma, deduzimos que as sociedades indígenas no contexto de colonização e formação de uma nação brasileira, eram as culturas mais "fracas", julgamos pela ausência da escrita, pois um dos princípios de Maquiavel em "O Príncipe" é que para se dominar um povo ou uma nação basta extinguir sua língua. Como os povos indígenas possuíam apenas o uso da língua na oralidade, sem registros, sem uma estratificação, era meio caminho andado para a dominação.

No entanto, em contraponto a esta "fraqueza", ignorávamos que essas sociedades/culturas, antes da chegada do não índio em suas terras já existiam há séculos, graças aos sustentáculos da tradição, a fé na sua cultura, no respeito à ancestralidade e à natureza. Ao perceber este fato, Fernandes ${ }^{8}$ menciona que estudiosos da antropologia abandonam os conceitos da aculturação, pois após séculos de contato, as sociedades indígenas não desapareceram como seria previsível por tal teoria; é claro que estas sociedades sofreram transformações durante o processo histórico, persistiram e se apresentam ainda de forma diferenciada da sociedade nacional.

Além disso, há que se considerar de que forma ocorrem os empréstimos de bens da sociedade nacional. Geralmente, um bem adotado por um grupo indígena sofre uma nova leitura. Isso é claro, pois um objeto, quando colocado fora do seu contexto original, terá nova interpretação. ${ }^{9}$

Teóricos e escritores como Fernando Ortiz citam uma nova terminologia para descrever esse processo de contato, que é a transculturação, que se estabelece não na base da superposição ou aniquilamento de uma em detrimento da outra, mas sim na troca, ou como cita Fernandes, no "empréstimo de bens", neste caso tanto a cultura indígena como a branca, trocaram bens. As particularidades da cultura indígena fluíram na sociedade ocidental, às vezes nem são notadas, mas estão presentes na nomenclatura, nos mitos e lendas, na culinária e até mesmo religiosamente.

6 MUNDURUKU, Daniel. Literatura indígena: um movimento que se expande. Disponível em <http://www.inbrapi.org.br/abre_artigo. php?artigo=7 > Acesso 07/I I/2007.

7 FERNANDES, Joana. Índio - Esse nosso desconhecido. Cuiabá: Editora da UFMT, 1993, pág. 17.

8 Ibidem.

9 FERNANDES, Joana. Índio - Esse nosso desconhecido. Cuiabá: Editora da UFMT, 1993, pág. 18. 
A maior troca ocorreu com as sociedades indígenas ao assimilarem a língua padrão falada e escrita do não índio, para se estabelecerem e não continuarem à margem, sem direito a voz. Este conceito de troca e de uso consciente/voluntário data-se no Brasil a partir dos últimos séculos, com a organização e movimentação social dos grupos indígenas, mas não podemos esquecer que é fruto de um processo bárbaro iniciado no século XVI com a chegada do outro olhar, que em nome de uma fé e da coroa catequizavam a força os índios brasileiros. Para Bonnici "Na vinda dos missionários religiosos e dos missionários lingüistas, o objetivo não era aprender a língua do outro para estabelecer um elo de comunicação procedente entre os povos ali representados, mas sim de catequizar o nativo".."

Esse processo leva à desestruturação do mundo indígena pela "ação conjugada de poderes e capitães". Enquanto os soldados do rei cuidavam da "ação conjugada de poderes e capitães", cabia aos jesuítas a "desintegração espiritual, pela supressão de um pensamento indígena milenar e a imposição de um novo imaginário"."

A partir desses pressupostos, focalizaremos novamente como o processo de escrita, surge e se organiza nas sociedades indígenas: segundo Antônio Cândido, "os povos primitivos distinguem essencialmente como nós o lógico e o mágico, embora em sua mente ambos formem configurações diversas, desta forma, o mágico sobressai proporcionalmente mais do que o lógico no tecido da sua existência."'12

Desta forma, podemos destacar que a escrita, literária ou não, produzida por autores indígenas, está impregnada desse mundo maravilhoso, mágico. Ou, na sua acepção mais clara, o mundo mítico, que antes do contato e da necessidade da escrita, ocorria na interpretação oral, no mergulho ao mundo embrenhado de subjetividade e não ao mundo concreto e questionável da palavra escrita, que em sua forma ficcional torna-se subjetivo novamente. No entanto, ao adquirirem o potencial da escrita e da educação formal da sociedade não indígena, esse processo de pensar o mítico, o mágico, é direcionado por uma lógica e pelas regras do outro, desde as normas gramaticais, ortográficas, semânticas, até as normas de produção cientifica.

Santos e Wielewicki'3 ${ }^{13}$ destacam que no século $X X$ a posição do índio não mudou muito em relação aos séculos passados, ainda permanecem subjugados, limitados às reservas, levando-os, na maioria das vezes, a tornarem-se dependente da cultura branca. Entretanto, também, destacam alguns aspectos positivos: graças à Constituição de 1988 que tornou oficial a existência das línguas indígenas no Brasil, possibilitando que nas escolas indígenas ela passe a ser usada como primeira língua e o português como segunda ou terceira língua.

I0 SANTOS, Célia Regina dos \& WIELEWICKI, Vera Helena Gomes. "Literatura de autoria de minorias étnicas e sexuais" in BONNICl, Thomas \& ZOLIN, Lúcia Osana (orgs.). Teoria literária: abordagens históricas e tendências contemporâneas. Maringá: EDUEM, 2005, pág. 287.

II Ibidem.

I2 CÂNDIDO, Antonio. Literatura e Sociedade: estudos de teoria e história literária. São Paulo: Editora Nacional, $4^{\mathrm{a}}$ ed. revisada, 1975 , pág. 42.

13 SANTOS, Célia Regina dos; WIELEWICKI, Vera Helena Gomes, op. cit. pág. 287. 
A criação de uma escola bilíngüe entre as comunidades indígenas abriu para um novo texto sobre o índio e para o índio. Apesar de em sua maioria serem de cunho antropológico e educacional (registros e transcrições de histórias contadas pelos índios e transformadas em material didático $)^{14}$.

Poderíamos dizer que a gênese da literatura indígena de cunho do próprio índio, nasceu paralelamente à criação da escola indígena, pois com incentivos do Estado foram fomentados projetos para produção de materiais paradidáticos. Muitos livros sobre as culturas e povos indígenas foram publicados com intuito de fortalecer a educação indígena. Sendo que na época essas histórias eram elaboradas de acordo com a percepção política e consciência histórica de cada povo.

fato de o índio tomar as rédeas de sua história parecia utopia, no entanto, hoje temos nos índios a visão de antropólogos e pesquisadores de sua própria sociedade, transmitindo aos seus leitores, geralmente as crianças, nas escolas indígenas, uma educação por meio da escrita, da literatura, mesmo que com fins didáticos. O importante é o diálogo que esse tipo de veiculação da língua promoverá com a comunidade, pois, ao elaborar registros escritos das narrativas de tradições orais, mantém uma imortalidade das histórias e culturas indígenas. ${ }^{15}$

A Literatura Indígena avança e se projeta além do universo didático, um grupo de escritores indígenas apontaram para o cenário literário nacional e internacional, ou seja, investiram nas suas carreiras de escritores, seja por um projeto individual ou por uma causa coletiva, por uma necessidade de defender e afirmar as identidades e ideologias de seus grupos. Citemos alguns representantes: Eliane Potiguara, Daniel Munduruku, Renê Kithãulu, Yaguarê Yamã e Olívio Jekupé entre outros. Nas condições propícias criadas pela pós-modernidade, a literatura feita pelos índios avança contribuindo possivelmente para o desenvolvimento de novas formas literárias. Segundo Mary Louise Pratt, as nações indígenas das Américas "encontram uma oportunidade para afirmar uma contra-história, resgatar seus costumes e consolidar as lutas atuais por território e autonomia. Intelectuais são convocados para definir, ou redefinir, sua relação com as estruturas de conhecimento e poder que produzem". ${ }^{6}$

Engajamento: questões de identidade em Banquete dos deuses: conversa sobre a origem da cultura brasileira de Daniel Munduruku

Um dos nomes mais reverenciados nos estudos da literatura engajada é o francês Jean-Paul Sartre, com a obra "O que é a Literatura?" I7 Sartre argumenta que o escritor engajado, por meio da literatura, constitui um canal de combate, de denúncia, ou seja, que em seus textos literários estão presentes um conteúdo discursivo de enfrentamento, que tem um cunho ideológico definido.

14 Ibidem,

15 Ibidem

16 PRATT, Mary Louise. Os olhos do império: relatos de viagem e transculturação. Bauru: EDUSC, 1999, pág. 20.

17 SARTRE, Jean-Paul. O que é a Literatura? São Paulo: Ática, 1989. 
Segundo Sartre, este posicionamento engajado e sua crítica tiveram seu ápice após a Segunda Guerra Mundial, quando a Europa arrasada pelas barbáries do nazismo, começa seu processo de reconstrução. Neste contexto, os escritores tomados pelo desejo de denunciar as atrocidades cometidas pelo regime nazista engajam-se por meio da literatura. Sartre não renega a "literatura estética", ao dar uma função à literatura. Apesar de tecer algumas críticas sobre a arte pela arte:

Sabe-se que uma arte pura e arte vazia são a mesma coisa, e que purismo estético foi apenas uma brilhante manobra defensiva dos burgueses do século passado, que achavam melhor ser denunciados como filisteus do que como exploradores. ${ }^{18}$

Vemos na citação de Sartre que cabe ao escritor dar o caráter à sua produção, portanto há os que se definem por uma causa, assim como há os que preferem ser ou não definidos. Denis ${ }^{19}$ diz que os esforços de Sartre consistem em não recusar a dimensão estética de uma obra, mas de torná-la um fator secundário e fazendo-a depender uma natureza essencialmente ética.

Nestes termos consideramos Daniel Munduruku como um escritor engajado da literatura indígena. Vejamos uma breve biografia. Ele nasceu em Belém do Pará em 1964, na sua infância viveu entre a aldeia dos munduruku e a cidade, até deixar definitivamente a aldeia para seguir com seus estudos na cidade e em 1987 foi para o interior de São Paulo, onde obteve os títulos de historiador e psicólogo e fez Mestrado em Antropologia na USP, onde atualmente faz Doutorado.

Tornou-se Diretor do Inbrapi (Instituto Indígena Brasileiro para Propriedade Intelectual), e pesquisador do CNPq. Recebeu o prêmio Reconto da Fundação Nacional do Livro Infanto-Juvenil em 200 I por "As Serpentes que Roubaram a Noite e outros mitos" e o prêmio para obras voltadas à preservação da cultura brasileira, do CNPq, no ano de 2003. Também recebeu o prêmio Jabuti pela obra "Coisas de Índio - Versão Infantil" no ano de 2004, e o livro "Meu Avô Apolinário" foi laureado pela UNESCO com menção honrosa na categoria literatura para crianças e jovens na questão da tolerância. Daniel vem exercendo seu papel de mediador intelectual entre as culturas indígenas e não indígenas por meio de sua literatura. É um explorador do universo mítico e mágico da cultura indígena brasileira e busca este resgate histórico/literário nas narrativas orais dos vários povos indígenas do Brasil. Possui mais de 30 livros publicados e alguns deles foram traduzidos para o inglês.

Daniel Munduruku constitui-se como um índio que é atravessado por mais de uma identidade, por mais de uma filosofia, ideologia; é o que podemos chamar de transculturado, por sua própria figura (autodenominada indígena) descendente de um dos grupos étnicos que viveu e que ainda vive à margem em nossa sociedade, na condição de tutelado, por sua formação na intelectual na cultura do "branco", buscando sua autonomia como sujeito indígena e brasileiro. Segundo Ángel Rama,

I8 Ibidem, pág. 24.

19 BENOIT, Denis. Literatura e engajamento: de Pascal a Sartre. Bauru: EUUSC, 2002, pág. 69. 
Os escritores que em suas obras desenvolvem processos de transculturação respondem às circunstâncias e especificidades das culturas dentro das quais se formaram, às proposições e imposição exercidas sobre elas pela cultura modernizada e, portanto, ao tipo de conflito que é gerado entre ambas. ${ }^{20}$

Vemos que as palavras de Munduruku, seus escritos e posicionamentos ideológicos estão voltados aos grupos indígenas que nos dias atuais vivem sufocados entre as (pequenas) reservas indígenas e as grandes cidades. Dando a esse(s) grupo(s) e a seus indivíduos visibilidade e voz, buscando a afirmação de uma identidade (nova), para garantir o direito às terras indígenas e o direito à sua ancestralidade, pois é de posse de suas terras que os índios terão assegurado o poder de exercer e/ou de praticar a sua cultura, a sua ideologia de vida, tradições, etc. Por todo esse contexto ideológico em defesa das causas indígenas, consideramos Munduruku como um escritor engajado, ou se preferirmos um escritor indígena engajado.

O escritor é mediador por excelência, e o seu engajamento é a mediação. Mas, se é verdade que se deve pedir contas à sua obra a partir da sua condição, é preciso lembrar ainda que a sua condição não é apenas a de um homem em geral, mas também, precisamente, a de um escritor. É um judeu, talvez tcheco, e de origem rural. Mas é um escritor judeu, um escritor tcheco e de origem rural. ${ }^{21}$

Em estudos realizados sobre a literatura indígena, Maria das Graças Ferreira, mais conhecida como Graça Graúna, apresenta em sua tese de Doutorado pela Universidade Federal de Pernambuco um panorama sobre este movimento literário e seus autores:

Apesar da falta do seu reconhecimento na sociedade letrada, as vozes indígenas não se calam. O seu lugar está reservado na história de um outro mundo possível. Visando à construção desse mundo, os textos literários de autoria indígena tratam de uma série de problemas e perspectivas que tocam na questão identitária e que devem ser esclarecidos e confrontados com os textos não-indígenas, pois trata-se de uma questão muito delicada e muito debatida hoje entre os escritores indígenas. ${ }^{22}$

O ponto chave nesta citação está na afirmação que os textos literários de autoria indígena tratam dos problemas e perspectivas que atingem a questão da identidade indígena. Numa proposta de confronto com outros discursos, principalmente com os dos não índios, que em sua maioria tendem a ser preconceituosos, equivocados e até mesmo primitivos.

20 RAMA, Ángel. "Os processos de transculturação na narrativa latino-americana" in Aguiar Flavio \& Sandra Guardini T. Vasconcelos (orgs.). Ángel Rama. Literatura e cultura na América Latina. São Paulo: EDUSP, 200 I, pág. 225.

21 SARTRE, Jean-Paul. O que é a Literatura? São Paulo: Ática, 1989, pág. 62.

22 FERREIRA, Maria das Graças. Contrapontos da literatura indígena contemporânea no Brasil. Tese de Doutorado - Programa de Pós-Graduação em Letras, da Universidade Federal de Pernambuco. Recife: UFPE, 2003. 
Daniel Munduruku afirmou numa conferência feita na Feira Internacional do Livro de Bolonha no ano de 2004 que, antigamente, antes do contato e de todas as mudanças que ele trouxera, a escrita não era necessária, pois a sabedoria era obtida e mantida numa forma superior, que seria a dos sonhos, não havia crise de identidade.

Nossos antepassados acharam que não deviam registrar nada, pois sabiam que o que devia ser ensinado era acessível a todos os que estavam em sintonia profunda com a natureza e com o espírito dos ancestrais que tudo transmitem através do sonho. Nesta ocasião não havia crise de identidade, pois nossos pais sabiam tudo o que precisavam para viver plenamente sua passagem por este planeta. ${ }^{23}$

No entanto, "com a chegada do outro olhar" que é o olhar da ganância, exploração com fins de riqueza, um olhar de destruição e maus tempos, um encontro que demorou muito para ser exposto e submetido a uma reflexão pelos "colonizados" ou "vítimas" destes traumas. Após todos esses séculos de mudanças que o contato com a civilização ocidental trouxe para as comunidades indígenas, o que restou?, o que se transformou?, quem são? e quem é índio de verdade?

Joana Fernande ${ }^{24}$ faz referência às pesquisas realizadas por estudantes da Universidade Federal de Mato Grosso nos anos 90, constatando que na maioria dos livros didáticos utilizados pelos professores nas escolas da capital do estado, traziam para os alunos representação de um índio do passado, ou seja, "eles eram", "moravam", "viviam da caça e pesca", "adoravam o sol e a lua", "o pajé era o feiticeiro". Esse empobrecimento de informações sobre os povos indígenas limita a capacidade dos estudantes de realmente conhecerem quem são os índios do Brasil, assim como omite a existência dos vários grupos indígenas na contemporaneidade. Isto gera um distanciamento entre as culturas, pois coloca os índios no passado, como se já nem existissem mais.

Orlandii ${ }^{25}$ constatou também em seus estudos sobre as questões indígenas, que a participação do índio na formação da identidade nacional sempre foi negligenciada pelo Estado.

Sobre a afirmação de uma identidade por meio da literatura, Zilá Bernd ${ }^{26}$ nos diz que este fato se torna recorrente no momento em que "as literaturas minorizadas no interior dos campos literários hegemônicos recusam a classificação de literaturas periféricas, conexas e marginais e reivindicam um estatuto autônomo no interior do campo instituído". Como já citamos anteriormente, a literatura brasileira que permeava a fundação nacional não soube tratar o índio como ele merecia, é claro que ela guardou, na verdade, dois lugares para ele nessa nação: o mais poético e romântico, para o índio

23 MUNDURUKU, Daniel. Literatura indígena: um movimento que se expande. In Imbrapi, 2004. Disponível em <http://www.inbrapi. org.br/abre_artigo.php?artigo=7 > Acesso 07/1 I/2007.

24 FERNANDES, Joana. Índio - Esse nosso desconhecido. Cuiabá: Editora da UFMT, 1993, pág. 143.

25 ORLANDI, Eni Pulcinelli. Terra à vista!: discurso do confronto: velho e novo mundo. São Paulo: Cortez; Campinas: Ed. UNICAMP, 1990.

26 BERND, Zilá. Literatura e identidade nacional. 2. ed. Porto Alegre: Editora da UFRGS, 2003, pág. 15. 
aportuguesado, aquele descrito com os mesmos valores culturais do colonizador; para o outro a selvageria, o atraso, povos sem almas.

Nesse panorama de nação e modelo de literatura em que as sociedades indígenas não se vêm como são, segundo Bernd "estas literaturas de minorias, estão voltadas para a consolidação de um projeto identitário, o sujeito emergente procura reapropriar-se de um espaço existencial". ${ }^{27}$ É nessa perspectiva de afirmações e reflexões, que os escritores indígenas se engajam; está aí, no combate ao equivocado conceito de índio, calcificado no consciente da sociedade não indígena e até mesmo nos descendentes de indígenas. Pois, têm-se como fontes de disseminação desse mau conceito, a escola, os livros didáticos, a história e as literaturas, que tratavam os índios com ênfase nas características distintas, enfatizando de forma demonizada as diferentes representações culturais como o ritual antropofágico, que faziam dos índios canibais vorazes e assustadores, como assassinos, povos sem alma. Transferindo sempre estereótipos pejorativos sobre o outro, sobre o desconhecido, salvo aqueles que eram à imagem do colonizador e cristãos confessados.

Edouard Glissant, em estudos sobre a formação de literaturas nacionais:

...há a função de dessacralização, função de desmontagem das engrenagens de um sistema dado, de pôr a nu os mecanismos escondidos de desmistificar. Há também uma função de sacralização, de união da comunidade em torno de seus mitos, de suas crenças, de seu imaginário ou de sua ideologia. ${ }^{28}$

Segundo Zilá Bernd ${ }^{29}$, o conceito de identidade carrega armadilhas e a mais perigosa é o anseio legítimo de afirmação identitária como, por exemplo, a afirmação de identidade pela "negritude", que corre o risco de se transformar num sistema "estanque". O que geraria a cristalização desses discursos criando propositalmente ou não um cordão de isolamento entre os cidadãos. Portanto, o mais cabível na visão da autora é o processo de identificação, que nos remete a uma situação de ação, ou seja, não se solidifica no tempo e espaço, mas está sempre em transformação e adaptandose aos anseios de determinados grupos e/ou indivíduos.

A Literatura Indígena de Munduruku tem essa função dessacralizadora quando apresenta um indígena discorrendo sobre sua identidade e de certa forma procura a sacralização, ou seja, manter e afirmar como uma verdade seu pensamento ideológico sobre a identidade indígena. Discurso identitário que talvez daqui a alguns anos, será contestado se alguns de seus pares não se identificarem com esse índio que Daniel apresenta e representa. Por isso a importância de um processo de identificação na formação ou constituição de uma identidade cultural.

Daniel Munduruku, em Banquete dos Deuses - Conversa sobre a origem da cultura brasileira, nos presenteia com um "manual", porque ao abri-lo nos encontraremos com um outro olhar sobre as

\footnotetext{
27 Ibidem.

28 BERND Apud, Zilá. Op. cit., pág. 19.

29 BERND, Zilá. Op. cit., pág. 21.
} 
relações entre as diferenças, entre brancos e índios, sobre aspectos culturais, educacionais, políticos e sociais etc. É uma produção com dez ensaios em que o autor apresenta reflexões sobre aspectos polêmicos que rodeiam as relações entre os povos indígenas e não índios, reforçando as discussões sobre a identidade cultural do índio "brasileiro" ${ }^{30}$. No entanto para não prolongarmos muito este estudo aportaremos alguns capítulos e seus fragmentos. $\bigcirc$ ensaio Em Busca de Uma Ancestralidade Brasileira - À guisa de introdução traz como epígrafe Carlos Drummond de Andrade, que nos convida a refletir sobre o Ser.

O importante é não estar aqui ou ali, mas SER. E ser é uma ciência feita de pequenas e grandes observações do cotidiano dentro e fora da pessoa. Quando não executamos essas observações, não chegamos a ser; apenas estamos desaparecendo. ${ }^{31}$

A discussão do Ser é exatamente o que vai direcionar o pensamento de Munduruku. Para ser índio não é preciso estar na aldeia, mas sim cultivar a suas tradições, de forma intima e pessoal ou coletiva?

Nasci índio. Foi aos poucos, no entanto, que me aceitei índio. Tinha vergonha, pois o fato de ser índio estava ligado a uma série de chavões que se cuspiam em mim: índio e atrasado, é sujo, preguiçoso, malandro, vadio... Eu não me identificava com isso, mas nunca fiz nada pra defender minha origem. ${ }^{32}$

A citação acima dialoga claramente com o que Bernd ${ }^{33}$ nos apresenta sobre o processo de identificação, que é validado pelo autor, quando ele afirma que não se identificava com aquilo que os outros diziam sobre ele. $\bigcirc$ que nos leva a considerar que há uma outra imagem, um outro discurso ao qual ele se identifica. Sendo assim, ele mesmo apresenta e faz-se conhecer qual seria esse discurso de identificação.

Uma solução é fazer com que os alunos busquem sua ancestralidade. É preciso trazer a figura dos antepassados para dentro da escola. Trazer suas histórias, seus comprometimentos, suas angústias, sua humanidade. É preciso fazer com que nossas crianças possam buscar a riqueza dos ancestrais, dos avós, bisavós. É preciso abrir espaço na escola para que o velho avô venha contar histórias que ele ouvia na sua época de criança, e ensine e cante as crianças de roda. ${ }^{34}$

30 Diz-se o índio "brasileiro" porque Munduruku não apresenta em seus textos uma etnia específica, sendo assim não referencia um grupo indígena em particular. O que entendemos como uma universalização do índio, assim como a cultura e as expressões culturais do não índio fez até os dias de hoje. É sabido que existem vários povos indígenas no Brasil, cada um com suas particularidades culturais, principalmente as linguísticas. Seria o correto: as identidades dos "índios brasileiros" ao invés de "índio brasileiro"?

3I ANDRADE, Carlos Drummond de. In. MUNDURUKU, Daniel. Op. cit., pág. 9.

32 MUNDURUKU, Daniel. Op. Cit., pág. 9.

33 BERND, Zilá. Op. Cit.

34 MUNDURUKU, Daniel. Op. Cit., pág. 16. 
O índio com quem ele se identifica é aquele que está na base da construção e formação da sociedade brasileira. Busca o lugar da ancestralidade, da sabedoria secular dos povos indígenas. Para Munduruku, esse reconhecimento e valorização da cultura do índio pelo outro "talvez crie uma nova identidade para o povo brasileiro e o ajude a descobrir a semente de suas origens...". ${ }^{35}$

Daniel Munduruku define bem esta ligação histórica e genealógica com a formação da nacionalidade brasileira: "... somos a continuação de um fio que nasceu muito tempo atrás... vindo de outros lugares... iniciado por outras pessoas... completado, remendado, costurado e... continuado por nós". ${ }^{36}$

Neste mesmo artigo, Daniel Munduruku nos diz que entre os índios não existe crise existencial, pois entre eles não se criam angústias.

As crises nascem da angústia. A angústia nasce entre a necessidade de escolher... Isso vira um circulo vicioso, e o vicio torna a vida uma busca insana pela felicidade (...). As pessoas não têm onde se apegar, pois não têm uma tradição, uma ancestralidade. $\bigcirc$ índio não tem crise existencial porque vive o presente, sem esquecer o passado e sem desejar o futuro. ${ }^{37}$

No entanto, no final do texto o autor afirma viver tal crise identitária. Portanto, se contradiz, afinal de contas ele assume sua identidade indígena. "É isso que eu sentia quando ouvia as histórias de meu avô e fez-me superar minhas crises de identidade e compreender as coisas que são importantes para meu povo"38. Ou isso não será uma crise existencial?

Já no ensaio Quanto custa ser índio no Brasil? - As imagens dos povos indígenas no inconsciente e no livro didático, Daniel relata que uma senhora o procura para lhe pedir um favor, que seria conhecer a sua filha, porque a menina de apenas seis anos de idade, não podia ouvir falar de índio que sentia medo. Esse encontro com ele tinha como objetivo da criança verificar que ele (índio) não era como as pessoas (professores) diziam: "ferozes", "selvagens", "comedores de gente", como nas imagens que ela tinha visto nos livros da escola.

Com esse expediente, pude constatar que o que estava por trás do "medo de índio" era a fala da escola e da professora. Segundo minha nova amiguinha, sua professora tinha apresentado apenas os aspectos negativos das populações indígenas e nada do que a gente tinha conversado naquele momento. Não preciso dizer que aproveitei o momento para tirar da cabeça dela as ideias que the tinham sido incutidas. Felizmente ela entendeu... e viu que eu era gente também. ${ }^{39}$

\footnotetext{
35 Ibidem, pág. 17.

36 Ibidem, pág. 14.

37 Ibidem.

38 Ibidem, pág. 27.

39 Ibidem, págs. 20-I.
} 
Munduruku relata que muitas vezes as pessoas que o abordam perguntam se ele é japonês, chileno e, só depois, é índio? Segundo o autor "elas partem do mais importante, mais inteligente, mais culto até chegarem ao nativo". E que depois que o identificam como índio, as pessoas tendem também a dizer que também são descendentes "dos bugres legítimos".

Acho isso intrigante, num primeiro momento. As pessoas sabem que os índios são "os verdadeiros donos da terra" e conseguem até se identificar com sua cultura, mas não assumem sua identidade logo de início, talvez por pensarem no nativo como sinônimo de selvagem. ${ }^{40}$

Mas existe o outro lado que é a negação de pertencimento à descendência indígena, que pode ocorrer devido aos conceitos pejorativos ou preconceituosos que estão agregados à identidade cultural do ser indígena.

Os manuais didáticos ajudam a formar uma visão distorcida sobre os índios. Isso porque eles trazem uma imagem estereotipada: os nativos são sempre apresentados como seres que vivem nus, nas matas, habitando em ocas ou tabas e que cultuam diversos deuses, entre os quais Tupã. $\bigcirc$ que esse tipo de informação pode gerar? Normalmente gera sentimentos equivocados, preconceitos e, por conseguinte, um comportamento discriminatório, típico de pessoas que têm opinião arbitrária sobre um grupo ou pessoa que se destaca pela diversidade cultural. ${ }^{41}$

Por outro lado, se toda sociedade está sujeita a uma leitura etnocêntrica das outras sociedades, o mesmo não pode ser estendido ao individuo. $\bigcirc$ individuo aprende e comporta-se de determinada maneira pela força da educação. ${ }^{42}$

Durante os anos 60, o pensamento político já concebia a escola como um aparelho ideológico usado pelo Estado para passar aos educandos uma visão de mundo baseada no modelo que o próprio Estado queria para si mesmo. ${ }^{43}$

Vemos que Banquete dos Deuses - Conversa sobre a origem da cultura brasileira, está permeado de uma conscientização sociopolítica muito explícita. De acordo com Denis Benoit, a literatura engajada é "uma prática literária estreitamente associada à política, aos debates gerados por ela e aos combates que ela implica". E o que é um escritor engajado? "Seria em resumo um autor que faz política nos seus livros". ${ }^{4}$

40 Ibidem.

41 Ibidem, pág. 22.

42 Ibidem.

43 Ibidem, pág. 23.

44 BENOIT, Denis. Literatura e engajamento: de Pascal a Sartre. Bauru: EdUSC, 2002, pág. 9. 
Se quisermos pensar no "descobrimento", temos de negar a história dos que são nativos de nossa terra. $\bigcirc$ termo descobrimento relaciona-se com a Europa e com todas as razões da colonização. Silencia a respeito dos conflitos entre portugueses e nativos e dos objetivos da colonização, baseados na expropriação territorial, na escravização e na destribalização. ${ }^{45}$

No ensaio "O País sobre um Cemitério, Direitos, Terra e Violência", evidencia-se uma acidez maior nas críticas feitas por autores indígenas à sociedade capitalista não índia. Já na epigrafe está uma frase de Ailton Krenak que diz: "O Brasil está se construindo em cima de um cemitério."

O Brasil não é apenas as grandes cidades. $\bigcirc$ Brasil é muito maior que a mesquinharia regional debatida por alguns políticos. $\bigcirc$ Brasil é uma grande casa com todos os seus cômodos e o seu quintal, e olhar apenas as grandes cidades é olhar para a sala e esquecer os outros cômodos. ${ }^{46}$

Daniel Munduruku procura chamar nesse texto a atenção do leitor para as realidades em que vivem os povos indígenas brasileiros: "E o povo brasileiro tem cuidado muito pouco da casa em que mora. Fica sentado na varanda, tomando conta da rua; enquanto isso, o quintal e a casa dele são roubados, mexidos, envenenados. Mas ele está muito seguro de si, sentado na varanda." ${ }^{47}$

E, numa expressão mais irônica, Munduruku cita a fala de um dos lideres do movimento indígena no Brasil, José Luiz Xavante.

O branco não sabe o que é a natureza, o que é o rio, o que são as árvores, o que é a montanha, o que é o mar... Em vez de respeitar, destrói, corta pedaço, joga coisas, polui o mar, os rios. Você vai me dizer: o índio está falando, mas é selvagem; selvagem é você, milhões de anos estudando e nunca aprendeu a ser civilizado. Para que você está estudando? Para destruir a natureza e no fim destruir a própria vida? ${ }^{24}$

De acordo com Munduruku a resistência indígena, com o passar dos anos, obteve algumas conquistas e avanços. Na década de 80 do século $\mathrm{XX}$, com o processo de abertura política, muitas organizações indígenas foram sendo criadas para fazer frente à violência contra os povos indígenas. Nesse contexto surgem no movimento os escritores indígenas, numa frente intelectual que continuou gerando novos líderes que surgiram para manter a esperança viva da tradição, constituindo um movimento de resistência.

\footnotetext{
45 MUNDURUKU, Daniel. Op. Cit., pág. 26.

46 Ibidem, pág. 80.

47 Ibidem, pág. 81.

48 Ibidem, pág. 90.
} 
Os indígenas literatos são frutos de uma resistência que vem de longo tempo. Cada vez mais jovens indígenas estão buscando registrar as histórias orais de seus antepassados para mostrá-las à sociedade brasileira e diminuindo a distância que sempre houve entre estes dois mundos. Saber que estamos auxiliando a sociedade brasileira a se conhecer melhor, já é um grande feito. ${ }^{49}$

Para Munduruku o movimento indígena tornou-se indígenas em movimento, pois a fórmula tradicional de organização já não respondia aos interesses de cada povo em particular. Dessa maneira, muitos indígenas colocaram seus pés na estrada e foram estudar preparar-se, para o enfrentamento, acreditando que a única forma de mudar a relação com a sociedade nacional é pela conscientização das pessoas.

\section{Conclusão}

Para melhor abordar esta literatura de autoria indígena recorremos novamente a Antonio Cândido que define quando é que existe a literatura:

não há literatura enquanto não houver essa congregação espiritual e formal, manifestando-se por meio de homens pertencentes a um grupo (embora ideal), segundo um estilo (embora nem sempre tenham consciência dele); enquanto não houver um sistema de valores que enforme a sua produção e dê sentido à sua atividade; enquanto não houver outros homens (um público) aptos a criar ressonância a uma e outra; enquanto finalmente não se estabelecer a continuidade (uma transmissão e uma herança), que signifique a integridade do espírito criador na dimensão do tempo. ${ }^{50}$

Vemos que o que mais existe na Literatura Indígena, da qual Daniel Munduruku faz parte, é essa comunhão entre "espírito" e "forma". Isso ocorre por meio da expressão do ser indígena, de sua essência, de seus mitos, por meio da "forma" escritural do outro (língua portuguesa padrão) para exprimir tal conteúdo. Munduruku busca a formação de um público leitor para sua literatura, a indígena, talvez por isso suas obras em sua maioria são dirigidas ao publico infanto-juvenil. E fundamentalmente, abre as portas para novos escritores indígenas, tanto para os seus contemporâneos, quanto para as gerações futuras. Talvez o ponto fraco desta literatura, seja que ela ainda não possua um campo de investigação crítico literário estabelecido, que lhe dê suporte e sedimentação para uma canonização.

49 MUNDURUKU, Daniel. Literatura indígena: um movimento que se expande. In Artigos site Imbrapi, 2004. Disponível em <http:// www.inbrapi.org.br/abre_artigo.php?artigo=7 > Acesso 07/I I/2007.

50 CÂNDIDO, Antonio. Op. cit., pág. 139. 
Consideramos que a figura do escritor indígena Daniel Munduruku no cenário literário causa certo estranhamento, pois não é tradição em nosso país escritores índios falando de si, de sua cultura a partir do seu olhar e de suas ideologias. Desta forma, lhe é remetido o lugar de engajamento, e seus escritos e obras não podem ser mesmo diferentes, pois neles estão contidos séculos de silêncio, de dor, de injustiça e da vontade de dizer.

O índio e a terra e a terra são marcas registradas do Brasil. Sem os índios, o Brasil fica mais pobre, a humanidade fica mais pobre, o planeta fica mais pobre. Acabamse os referenciais da ancestralidade. É preciso acabar com o distanciamento que existe entre o povo brasileiro e os povos indígenas. $O$ índio é brasileiro, o brasileiro é também índio. ${ }^{51}$

Esta literatura traz um conteúdo que precisa ser lido, pensado, praticado e ela nos apresenta funções, seja de caráter social, ideológico, político e porque não artístico? Com a proposta de construir novas formas de olhares, produções híbridas. Uma nova maneira de ver o outro, de perceber o outro e saber o que outro tem a dizer e a ensinar e principalmente de reconhecer e se identificar com este outro. (Re)conhecer o outro, é onde está a raiz da arte poética das narrativas de Munduruku. Numa literatura de afirmação de sua identidade pelas diferenças, sobretudo numa igualdade, a de sermos um só povo: "brasileiros".

Vemos como "regionalização" 52 as ações dos escritores indígenas brasileiros ao conduzirem pela escrita do outro, estratégia que pode ser vista como um meio de legitimação e alcance dos leitores que esses escritores querem atingir. De acordo com Manuel Castells:

Se a maioria das vezes, o nacionalismo representa uma reação contra ameaças a uma determinada identidade autônoma, num mundo submetido à ideologia da modernização e ao poder dos media globais, a língua, como expressão directa da cultura, torna-se a trincheira da resistência cultural, o último bastião do autocontrole, o reduto do significado identificável..$^{53}$

Quando os próprios indígenas partem nesse movimento de fazer da língua, em nosso caso a escrita, um meio, um instrumento direto de contato com o outro, estabelecendo uma nova dinâmica, perde-se a ideia de que as identidades nacionais partem do pressuposto de "comunidades imaginadas" e de que são apenas construídas a serviço de aparelhos de poder, mas "pelo contrário, são produzidas pelos esforços de uma história compartilhada e reflectida nas linguagens comunais através duma primeira palavra: nós, duma segunda: a nós e, infelizmente, duma terceira: eles" 54

5I MUNDURUKU, Daniel. Op. cit., pág. 87.

52 Termo baseado no regionalismo, fenômeno literário muito bem analisado por Angel Rama em Literatura e cultura na América Latina (200I).

53 CASTELLS, Manuel. O poder da identidade. Lisboa: Fundação Calouste Gulbenkian, 2003, pág. 63.

54 Ibidem. 


\section{Bibliografía}

BERND, Zilá. Literatura e identidade nacional. 2. ed. Porto Alegre: Editora da UFRGS, 2003.

BENOIT, Denis. Literatura e engajamento: de Pascal a Sartre. Bauru: EdUSC, 2002.

BONNICl, T. Teoria literária: abordagens históricas e tendências contemporâneas. 8. ed. Maringá: Eduem, 2005.

CASTELLS, Manuel. O poder da identidade. Lisboa: Fundação Calouste Gulbenkian, 2003.

CÂNDIDO, Antonio. Literatura e Sociedade: estudos de teoria e história literária. 4ed. rev. São Paulo: Editora Nacional, 1975.

FERNANDES, Joana. Índio-Esse nosso desconhecido. Cuiabá: Editora da UFMT, 1993.

FERREIRA, Maria das Graças. Contrapontos da literatura indígena contemporânea no Brasil. Tese de Doutorado Programa de Pós-Graduação em Letras, da Universidade Federal de Pernambuco. Recife: UFPE, 2003

MUNDURUKU, Daniel. Banquete dos Deuses - Conversa sobre a origem da cultura brasileira. São Paulo: Angra, 2000.

MUNDURUKU, Daniel. LITERATURA INDÍGENA: UM MOVIMENTO QUE SE EXPANDE. In. Artigos site Imbrapi, 2004. Disponível em <http://www.inbrapi.org.br/abre_artigo.php?artigo=7 > Acesso 07// I/07.

ORLANDI, Eni Pulcinelli. Terra à vistal: discurso do confronto: velho e novo mundo. São Paulo: Cortez; Campinas: Ed. UNICAMP, 1990.

PRATT, Mary Louise. Os olhos do império: relatos de viagem e transculturação. Bauru, SP: EDUSC, 1999.

RAMA, Angel. Literatura e cultura na América Latina. Org. Flavio Aguiar, Sandra Guardini T. Vasconcelos. São Paulo: EDUSP, 2001.

SANTOS, Célia Regina dos; WIELEWICKI, Vera Helena Gomes. Literatura de autoria de minorias étnicas e sexuais. In BONNICl, Thomas; ZOLIN, Lucia Osana (orgs.) Teoria literária: abordagens históricas e tendências contemporâneas. 2. ed. Maringá: UEM, 2005.

SARTRE, Jean-Paul. O que é a Literatura? São Paulo. Ática, 1989. 